\title{
Effect of Leguminous Cover Crops on Soil Biological Activity in Pots of Citrus Unshiu Marcovitch
}

\author{
Fiorella Stagno $^{1}$, Cristina Abbate ${ }^{* 2}$, Francesco Intrigliolo ${ }^{1}$, Valerio Abbate $^{3}$, \\ Mara Gennari ${ }^{2}$ \\ ${ }^{1}$ CRA, Istituto Sperimentale per l'Agrumicoltura \\ Corso Savoia 190, 95024 Acireale (CT), Italy \\ ${ }^{2}$ Dipartimento di Scienze Agronomiche, Agrochimiche e delle Produzioni Animali, \\ Sezione di Scienze Agrochimiche, Università di Catania \\ Via Santa Sofia 98, 95123 Catania, Italy \\ ${ }^{3}$ Dipartimento di Scienze Agronomiche, Agrochimiche e delle Produzioni Animali, \\ Sezione di Scienze Agronomiche, Università di Catania \\ Via Valdisavoia 5, 95123 Catania, Italy
}

Received: 30 May 2008. Accepted: 11 July 2008.

\begin{abstract}
Little is known about the effects of cover crops on soil properties in citrus orchards. To fill this gap, this work was aimed to determine the effects of leguminous cover crops on the chemical and biological properties of the soil and on the structure of the microbial community in pots of Citrus unshiu (Marcovitch). After amendment with cover crops, an increase in total organic C (TOC), total extractable C (TEC), and total N (TN) contents were observed irrespective of the type of soil. Substrate induced respiration (SIR), and potentially mineralisable nitrogen (PMN), tested three times in one year, were higher in soils with leguminous cover crops while no significant differences were observed in protease and deaminase activity. The effect on the chemical and biochemical properties of the soil was more evident in plots containing Trifolium subterraneum. No changes were observed in the microbial communities studied ( $\alpha$-proteobacteria, $\beta$-proteobacteria, nitrogen-fixing, and ammonia oxidizers) irrespective of the kind of cover crop or type of soil, neither were variations noted during the trial.
\end{abstract}

Key-words: cover crops, leguminous, citrus orchard, soil fertility, soil biological activity.

\section{Introduction}

Use of cover crops is a way of providing the soil with organic matter and nutrients, reducing erosion and limiting losses due to the leaching of nutrients thus preserving fertility (Dinnes et al., 2002; Logsdon et al., 2002). The use of cover crops helps to improve soil structure, improving both the water infiltration and aeration, thus reducing the risk of compaction (Sainju and Singh, 1997). Other effects produced are: increased water holding capacity, improved workability of the soil, an increased cation exchange capacity, and an increase in buffering capacity (Campiglia, 1999). Organic matter, even if it is only a minor solid component of the soil, plays an important role in overall fertility (Benedetti et al., 1998). Intrigliolo and Stagno (2001) found that even slight variations in organic matter content determine a noticeable change in the physical characteristics of the soil. Much has been written regarding the relationship between soil organic matter and the activity of the microbial biomass which is fundamental if there are to be balanced cycles of the main nutritive elements, N, P and S (Benedetti et al., 1998). Biological fertility refers, in particular, to those aspects of fertility closely connected to the presence and activity of living soil organisms. Given the complex nature of the organic residues in the soil, several species of micro-organisms are involved in transforming the organic matter. This is in- 
fluenced not only by the quantity of organic residues and the levels of microbial biomass, but also by different environmental parameters such as humidity, temperature and aeration. If biological fertility is absent then the soil is sterile and can no longer guarantee the correct growth conditions for plants (Nannipieri et al., 2005).

In recent years, different methods have been developed for analysing structure and diversity of soil microbial communities. These are divided into culture-dependent and culture-independent methods, and have been used to study microbial communities in agricultural soils in temperate climates. The use of molecular markers, such as the 16S rRNA gene, has been commonly applied to explore microbial diversity in environmental samples detecting, identifying and fingerprinting micro-organisms and microbial communities (Muyzer and Smalla, 1998).

In Mediterranean environments annual selfseeding legumes are the most suitable for inclusion in agricultural systems (Caporali and Campiglia, 1993). These species correspond fully to the principles of sustainability, in that they are able to exploit, add, conserve and recycle nutritive elements, control pathogens and weeds and improve the physical characteristics of the soil (Campiglia, 1999). Autumn and winter cover crops can be very important because, given that in this period plant roots begin to absorb less nutritive elements, in this way it is possible to retain a good quantity of elements which would otherwise be lost, washed deep into the ground by the particularly intense rainfall in these seasons. At the same time, they make it possible to mobilise the generally inaccessible reserves of elements such as phosphorus. This study evaluates the effect that legume crops sown in a citrus fruit orchard have on the biological activity of the soil, measured using the following analytical parameters: substrate induced respiration (SIR), potentially mineralisable nitrogen (PMN), proteasic and deaminasic activity and bacterial community composition (Amplified Ribosomal DNA Restriction Analysis and Denaturing Gradient Gel Electrophoresis). Moreover, the effect on the total organic $\mathrm{C}$ (TOC), total extractable C (TEC), humic substances (HS) and total N (TN) contents was evaluated after the crops had been kept in place for two years with biomass being incorporated into the soil.

\section{Materials and methods}

\section{Experimental set-up}

The research was carried out at the S. Salvatore experimental orchard (Acireale, Catania, Italy) belonging to the Citrus Fruit Cultivation Experimental Institute, using 8-year-old satsuma plants (Citrus unshiu Marcovitch) grafted onto bitter oranges (C. aurantium L.) in 300 litre capacity plastic pots. The pots were placed in the open air and drip-irrigated. The volume of water provided was $1.5 \mathrm{~m}^{3} /$ plant/year. Mean annual rainfall was $300 \mathrm{~mm}$. No fertilizer was used. The experimental design was a randomised complete block design with a $3 \times 3$ factorial arrangement of cover crop and soil type. The cover treatments were: a) Trifolium subterraneum; b) Medicago ciliaris; c) natural vegetation (control). The main weed species grown in the control pots were: Bromus spp., Calendula arvensis, Chrysanthemum segetum, Lolium rigidum, Poa апnиa. The soil types were: a) sandy soil (S); b) sandy-clay-loam soil (SCL); c) sandy-loam soil (SL). The treatments were repeated three times on 27 plots. During the first year of the experiment (2003-2004), both the legume crops were sown in September with a quantity of seeds equal to $250 \mathrm{seeds} / \mathrm{m}^{2}$. At the end of each growth cycle in the second (2004-2005) and third years (2005-2006), the quantity of cover crop seeds produced was calculated according to their self-seeding capacity and was found to be 7,711 seeds $/ \mathrm{m}^{2}$ and 5,800 seeds $/ \mathrm{m}^{2}$ for the $T$. subterraneum and 17,591 and 22,833 seeds $/ \mathrm{m}^{2}$ for the $M$. ciliaris in the two respective years. At the end of the growth cycle, that is at the end of June or beginning of July, the organic residues and seeds produced were incorporated into the soil. Two operations are necessary when a herbaceous crop is added to the soil by means of green manuring: the biomass must be shredded to aid decomposition (increasing the surface area exposed to attack by micro-organisms) and then the dried biomass must be turned into the soil. All the operations were carried out manually.

\section{Soil sampling and preparation}

The soil samples were taken from the pots at a depth of $0-15 \mathrm{~cm}$ where the roots of the cover crops were present. After collection the soil was sieved through a $2 \mathrm{~mm}$ screen then stored in 
field-moist conditions at $4{ }^{\circ} \mathrm{C}$. The samples for molecular analysis were kept at a temperature of $-25{ }^{\circ} \mathrm{C}$. To determine the biological activity of the soil, the samples were taken in the following periods: a) July 2004 (before incorporating the biomass into the soil and 10 months after sowing); b) November 2004 (4 months after biomass incorporation); c) February 2005 (seven months after biomass incorporation); d) July 2005 (one year after incorporation). The molecular analysis were performed on soil samples taken in July 2004 and in July 2006 (one year after the second incorporation). The TOC, TEC, $\mathrm{HS}$ and total $\mathrm{N}$ calculations were performed on the same samples.

\section{Determination of soil chemical and physical characteristics and microbial biomass activity}

The main chemical and physical characteristics of the soil were measured using the standard methods recommended by the Soil Science Society of America (Page et al., 1982). SIR determination was performed according to Anderson and Domsch (1978). Carbon dioxide evolution rates were measured using the alkali absorption method. Twenty g (on a dry basis) aliquots of the soils added with glucose $(4 \mathrm{mg} / \mathrm{g}$ dry soil) were placed in $500 \mathrm{ml}$ glass jars containing a vial which in turn contained $4 \mathrm{ml}$ of $1 \mathrm{~N} \mathrm{NaOH}$ solution to trap the $\mathrm{CO}_{2}$. After 6 hours the amounts of $\mathrm{CO}_{2}$ absorbed by the traps were measured by tritating $2 \mathrm{ml}$ aliquots with $0.1 \mathrm{~N}$ $\mathrm{HC} 1$ after previously adding $8 \mathrm{ml}$ of barium chloride $0.75 \mathrm{~N}$. To determine the PMN, $15 \mathrm{~g}$ (on a dry basis) moist soil samples were placed in $100 \mathrm{ml}$ polyethylene bottles then incubated at $30{ }^{\circ} \mathrm{C}$ for 28 days. Mineral $\mathrm{N}$ concentrations in $0.5 \mathrm{M} \mathrm{K}_{2} \mathrm{SO}_{4}$ soil extracts (1:4 soil:extractant w/v ratio) were analysed at 0 and 28 days (Drinkwater et al., 1996). $\mathrm{NH}_{4}-\mathrm{N}$ was determined using the indophenol-blue colorimetric method, while $\mathrm{NO}_{3}-\mathrm{N}+\mathrm{NO}_{2}-\mathrm{N}$ was quantified after reduction of $\mathrm{NO}_{3}-\mathrm{N}$ to $\mathrm{NO}_{2}-\mathrm{N}$ on a $\mathrm{Cu}-\mathrm{Cd}$ column, in accordance with Keeney and Nelson (1982). The $\mathrm{PMN}$ was calculated as the difference between $\mathrm{NH}_{4}-\mathrm{N}+\mathrm{NO}_{3}-\mathrm{N}+\mathrm{NO}_{2}-\mathrm{N}$ before and after incubation.

\section{Enzymatic determinations}

To study micro-organism activity further we decided to evaluate the activity of two enzymes involved in nitrogenous metabolism: proteases and deaminases. The two enzymes were determined according to Kandeler (1993a, 1993b). All the data underwent ANOVA analysis and the means were compared with the Tuckey test.

Extraction of Total Community DNA and $\mathrm{Nu}$ cleic Acid Amplification

DNA was extracted from the soil using the QIAamp DNA Stool Mini Kit following the manufacturer's instructions (Qiagen, Milan, Italy). The PCR was performed with a DNA Px2 thermocycler (Hybaid) using specific primers for the amplification of $\alpha$-, $\beta$-proteobacterial, nitrogenfixing and ammonia oxidiser bacteria $16 \mathrm{~S} \mathrm{rD}$ NA fragments. The reaction mixture for the amplification was: $1 \mu \mathrm{L}$ template DNA (about 40 $\mathrm{ng}), 400 \mu \mathrm{M}$ of dNTP, $1.5 \mathrm{mM} \mathrm{MgCl}, 5 \%(\mathrm{w} / \mathrm{v})$ DMSO, $400 \mu \mathrm{M}$ of the group-specific forward and reverse primers (Tab. 1) and 2.6 units of Taq DNA Polymerase in a buffered final volume of $50 \mu \mathrm{L}$ (Invitrogen, Milan, Italy). Bovine serum albumin (BSA) $(0.1 \mu \mathrm{M})$ was added to avoid organic compounds, co-extracted from the soil, from inhibiting amplification. The PCR conditions were: a hot start of 5 minutes at $94{ }^{\circ} \mathrm{C}, 35$ cycles consisting of 1 minute at $94{ }^{\circ} \mathrm{C}, 1$ minute at $56{ }^{\circ} \mathrm{C}$ ( $\alpha$-proteobacteria) / $61{ }^{\circ} \mathrm{C}$ ( $\beta$-proteobacteria) $/ 68{ }^{\circ} \mathrm{C}$ (nitrogen-fixing bacteria), 2 minutes at $72{ }^{\circ} \mathrm{C}$, followed by a final 10 minutes at $72^{\circ} \mathrm{C}$. For ammonia oxidiser bacteria, a "touchdown PCR" program was used: $94{ }^{\circ} \mathrm{C}$ for 1 minute, $64{ }^{\circ} \mathrm{C}$ for 1 minute, $72{ }^{\circ} \mathrm{C}$ for $3 \mathrm{~min}$ utes, for 2 cycles; subsequently, other 8 cycles were performed lowering the annealing temperature by $2{ }^{\circ} \mathrm{C}$ every 2 cycles until it reached $56{ }^{\circ} \mathrm{C}$ and the final 15 cycles consisted of $94{ }^{\circ} \mathrm{C}$ for 1 minute, $54{ }^{\circ} \mathrm{C}$ for 1 minute, $72{ }^{\circ} \mathrm{C}$ for 3 minutes, followed by a final 10 minutes elongation at $72{ }^{\circ} \mathrm{C}$. The PCR products, $5 \mu \mathrm{L}$ sub-samples, were examined by electrophoresis on $1 \mathrm{x}$ TAE agarose gel $(0.8 \% \mathrm{w} / \mathrm{v})$ stained with ethidium bromide $(0.5 \mu \mathrm{g} \mathrm{mL}-1)$ with appropriate DNA size standards (Mass Ruler ${ }^{\mathrm{TM}}$, DNA Ladder Mix and Fermentas) to evaluate the size and approximate quantity of the amplicons generated. For $\alpha$ - and $\beta$-proteobacteria, the PCR products $(1 \mu \mathrm{L})$ served as the template for a DGGEPCR.

\section{PCR amplification for DGGE analysis}

$\alpha$ - and $\beta$-proteobacteria were amplified with the F984GC and R1378 primer sets using the group- 
specific amplicons obtained, as described above, as template. Nitrogen-fixing and ammonia oxidiser bacteria were amplified with the following primer sets (FY1GC - Y2R) and (GCCTO189FA, B, C - CTO654R), respectively. DNA, directly extracted from the soil, was used as template. The reaction mixture used for the amplification of $16 \mathrm{~S}$ rDNA fragments for DGGE analysis was: $1 \mu \mathrm{L}$ of template, $250 \mu \mathrm{M}$ of dNTP, $1.5 \mathrm{mM} \mathrm{MgC1}{ }_{2}, 0.1 \mu \mathrm{M}$ BSA, $250 \mu \mathrm{M}$ of forward and reverse primers (Table 1) and 2.6 units of Taq DNA Polymerase in a buffered final solution of $50 \mu \mathrm{L}$ (Invitrogen). The PCR conditions were: $94{ }^{\circ} \mathrm{C}$ for 5 minutes followed by 30 cycles at $94{ }^{\circ} \mathrm{C}$ for 1 minute, $53{ }^{\circ} \mathrm{C}(\alpha-, \beta$ proteobacteria and nitrogen-fixing bacteria) / 57 ${ }^{\circ} \mathrm{C}$ (ammonia oxidisers) for 1 minute, $72{ }^{\circ} \mathrm{C}$ for 2 minutes and a final 10 minutes at $72{ }^{\circ} \mathrm{C}$. The amplicons were analysed as described above.

\section{Amplified Ribosomal DNA Restriction Analysis (ARDRA)}

The amplified 16 DNA products (400 ng) were digested separately for 3 hours with the restriction endonuclease TaqI (New England BioLabs, MA, USA) as specified by the manufacturer, but with an excess of enzyme (10 U per reaction). Restricted DNA was analysed by electrophoresis on $3.5 \%$ agarose gel at $30 \mathrm{~V}$ overnight and stained with ethidium bromide. Bands were detected from digital images (Po- laroid, Gel Cam, Elect; Polaroid Type 667 Film ISO 3000) by UV light gel transillumination $(\lambda$ $312 \mathrm{~nm}$ ).

\section{Denaturing Gradient Gel Electrophoresis analy-} sis (DGGE)

16S rDNA-DGGE was performed using the Dcode System (Universal Mutation Detection System, BIO-RAD). $300 \mathrm{ng}$ of amplicons were loaded (top filling method) onto $6 \%$ polyacrylamide gel (Acrylamide/Bisacrylamide, 40\%, 37.5:1, BIO-RAD) containing a denaturant gradient of $46-56 \%$ parallel to the electrophoresis direction made from urea and formamide (100\% denaturant contains $7 \mathrm{M}$ urea and $40 \%$ formamide). The gels were electrophoresed at a constant temperature $\left(60{ }^{\circ} \mathrm{C}\right)$ and voltage $(75$ V) for 16 hours, followed by 2 hours coloration using SYBR Green I nucleic acid gel stain 1:1000 diluted in the running buffer (FMC Bio Products, Rockland, ME, USA). Bands were detected from digital images (Polaroid Gel Cam, Elect; Polaroid Type 667 Film ISO 2000) by UV light gel transillumination $(\lambda 312 \mathrm{~nm})$.

\section{Results and discussion}

The three soils were significantly different as regards texture, $\mathrm{pH}$, active limestone, $\mathrm{TN}, \mathrm{TOC}$ ), TEC, and HS content. In particular, soil S appeared more acid, poorer in all forms of organ-

Table 1. Primer sequences used in the present study.

\begin{tabular}{|c|c|c|}
\hline Primer & Sequence 5' a 3' (16S rDNA target) & References \\
\hline $\mathrm{F} 203 \alpha$ & CCGCATACGCCCTACGGGGGAAAGATTTAT ( $\alpha$-Proteobacteria) & Gomes et al., 2001 \\
\hline F948 $\beta$ & CGCACAAGCGGTGGATGA ( $\beta$-Proteobacteria) & Gomes et al., 2001 \\
\hline R1494 & CTACGG(T/C)TACCTTGTTACGAC (Bacteria) & Weisburg et al., 1991 \\
\hline F984GC & AACGCGAAGAACCTTAC (Bacteria) & Heuer et al., 1997 \\
\hline R1378 & CGGTGTGTACAAGGCCCGGGAACG (Bacteria) & Heuer et al., 1997 \\
\hline Y1F & TGGCTCAGAACGAACGCTGGCGGC (Nitrogen-fixing bacteria) & Brosius et al., 1981 \\
\hline Y2R & CCCACTGCTGCCTCCCGTAGGAGT (Nitrogen-fixing bacteria) & Brosius et al., 1981 \\
\hline FY1GC & TGGCTCAGAACGAACGCTGGCGGC (Nitrogen-fixing bacteria) & Brosius et al., 1981 \\
\hline \multirow[t]{2}{*}{ GC-clamp } & CGCCCGGGGCGCGCCCCGGGCGGGGCGGG GGCACGGGGGG & \\
\hline & 5' attached to F984GC and FY1GC & Nübel et al., 1996 \\
\hline AMOXF & TGGGGRATAACGCAYCGAAAG (Ammonia oxidizers bacteria) & Smit et al., 1997 \\
\hline AMOXR & AGACTCCGATCCGGACTACG (Ammonia oxidizers bacteria) & Smit et al., 1997 \\
\hline \multirow[t]{2}{*}{ GCCTO189FA } & CCGCCGCGCGGCGGGCGGGGCGGGGGCACGGGGGGAGA & \\
\hline & AAAGCAGGGGATCG (Ammonia oxidizers bacteria) & Kowalchuk et al., 1997 \\
\hline \multirow[t]{2}{*}{ GCCTO189FB } & CCGCCGCGCGGCGGGCGGGGCGGGGGCACGGGGGGAGGA & \\
\hline & AAGCAGGGGATCG (Ammonia oxidizers bacteria) & Kowalchuk et al., 1997 \\
\hline \multirow[t]{2}{*}{ GCCTO189FC } & CCGCCGCGCGGCGGGCGGGGCGGGGGCACGGGGGGAGGA & \\
\hline & AAGTAGGGGATCG (Ammonia oxidizers bacteria) & Kowalchuk et al., 1997 \\
\hline CTO654R & CTAGCYTTGTAGTTTCAAACGC (Ammonia oxidizers bacteria) & Kowalchuk et al., 1997 \\
\hline
\end{tabular}


Table 2. Selected chemical and physical properties of the soils.

\begin{tabular}{lccc}
\hline Soil property & S & SCL & SL \\
\hline Clay (\%) & $2.4 \mathrm{a}$ & $21.2 \mathrm{c}$ & $11.3 \mathrm{~b}$ \\
Silt (\%) & $3.3 \mathrm{a}$ & $21.8 \mathrm{c}$ & $13.9 \mathrm{~b}$ \\
Sand (\%) & $94.3 \mathrm{c}$ & 57.0 & $74.8 \mathrm{~b}$ \\
$\mathrm{pH}(1: 2.5$ soil $\mathrm{KCl})$ & $5.8 \mathrm{a}$ & $7.4 \mathrm{ab}$ & $7.6 \mathrm{~b}$ \\
$\mathrm{pH}\left(1: 2.5\right.$ soil: $\left.\mathrm{H}_{2} \mathrm{O}\right)$ & $6.5 \mathrm{a}$ & $8.2 \mathrm{ab}$ & $8.5 \mathrm{~b}$ \\
Active limestone $(\%)$ & $0.37 \mathrm{a}$ & $6.44 \mathrm{~b}$ & $14.58 \mathrm{c}$ \\
Total N (TN, \%) & $0.91 \mathrm{a}$ & $1.88 \mathrm{c}$ & $1.44 \mathrm{~b}$ \\
Total organic carbon (TOC, \%) & $0.99 \mathrm{a}$ & $1.79 \mathrm{~b}$ & $1.19 \mathrm{a}$ \\
Extractable organic carbon (TEC, \%) & $0.66 \mathrm{a}$ & $1.10 \mathrm{~b}$ & $0.80 \mathrm{a}$ \\
Humic substances (HS, \%) & $0.48 \mathrm{a}$ & $0.74 \mathrm{~b}$ & $0.54 \mathrm{ab}$ \\
\hline
\end{tabular}

$\mathrm{S}=$ sandy soil; $\mathrm{SCL}=$ sandy-clay-loam soil; $\mathrm{SL}=$ sandy-loam soil.

Standard deviation $<10 \%$. Values followed by the same letters within the grouping of rows are not significantly different by the

F-test in the analysis of variance $(\mathrm{p}<0.05) ; \mathrm{n}=9)$.

ic matter and TN. Instead, the P content of the soil S was higher than the other two soils. Soil SCL was the richest in TOC, TEC, HS and TN. Soil SL contained the greatest quantity of active limestone and was consequently characterised by the highest $\mathrm{pH}$ (Tab. 2). Among the parameters considered in evaluating the chemical characteristics of the three soils, TOC, TEC, $\mathrm{HS}$ and TN content were measured both in July 2004 (before the first incorporation of biomass) and in July 2006 (before the third incorporation of biomass). Table 3 compares the relative percentage values of the samples taken in July 2006 compared with those of July 2004. An increase in TOC, TEC and TN can be seen in all the experimental conditions while the HS content was higher in the lots containing T. subterraneum, practically unchanged in the lots with $M$. ciliaris and $16 \%$ lower in the lots with spontaneous vegetation. As regards the TOC and $\mathrm{TN}$ the increases appear greater in the lots containing legumes, but only in the case of $T$. subterraneum was a significant difference seen as compared with the control. The increase in TEC was comparable in all three experimental conditions. Data collected from commercial dryland and irrigated legume crops indicated that 95-270 kg fixed $\mathrm{N} \mathrm{ha}^{-1}$ can remain in vegetative residues after harvesting (Peoples et al., 1995; Rochester et al., 1998; Schwenke et al., 1998). Spehn et al. (2002) found that the presence of legumes enhanced nitrogen availability for cooccurring species, which increased their biomass production and tissue nitrogen concentrations. The fixed nitrogen was made available to nonfixing neighboring plants by the mineralization of legume litter (Peoples and Crashwell, 1992). Comparing the trend of the parameters no relevant differences were observed with respect to the type of soil, even if in soil SL the increases appeared to be generally lower, probably due to its higher $\mathrm{pH}$.

The evaluation of the biological activity was performed only over a brief period with three measurements being made in the course of one year. The results of the analyses are shown in Table 4. The SIR was higher in those lots containing legumes as compared to the control, but the difference was only statistically significant in the case of $T$. subterraneum. The $\mathrm{N}^{-\mathrm{NH}_{3}}$ con-

Table 3. Effects of amendment with cover crops on selected soil chemical characteristics. Comparison between the soil samples collected on July 2004 and July 2006.

\begin{tabular}{|c|c|c|c|c|c|c|}
\hline \multirow[t]{2}{*}{ Soil property } & \multicolumn{3}{|c|}{ Comparison between cover crops } & \multicolumn{3}{|c|}{ Comparison between soils } \\
\hline & $\begin{array}{c}\text { T. subterraneum } \\
(\%)\end{array}$ & M. ciliaris & Control & $\mathrm{S}$ & SCL & $\mathrm{SL}$ \\
\hline Total N & 140 & 126 & 119 & 138 & 134 & 120 \\
\hline TOC & 130 & 124 & 121 & 120 & 135 & 120 \\
\hline TEC & 120 & 117 & 119 & 120 & 120 & 116 \\
\hline HS & 138 & 97 & 84 & 102 & 106 & 111 \\
\hline
\end{tabular}

$\mathrm{S}=$ sandy soil; $\mathrm{SCL}=$ sandy-clay-loam soil; $\mathrm{SL}=$ sandy-loam soil.

Standard deviation $<10 \% ;(\mathrm{n}=9)$. 
Table 4. Biological properties of the soils amended with cover crops.

\begin{tabular}{|c|c|c|c|c|c|c|}
\hline \multirow[t]{2}{*}{ Soil property } & \multicolumn{3}{|c|}{ Comparison between cover crops } & \multicolumn{3}{|c|}{ Comparison between soils } \\
\hline & T. subterraneum & M. ciliaris & Control & $\mathrm{S}$ & SCL & SL \\
\hline $\mathrm{SIR}\left(\mu \mathrm{g} \mathrm{C}-\mathrm{CO}_{2}\right)$ & $95.9 \mathrm{~b}$ & $78.3 \mathrm{ab}$ & $63.0 \mathrm{a}$ & $23,4 \mathrm{a}$ & 103. c & 76. b \\
\hline PMN $\left(\mu g_{g}{ }^{-1}\right)$ & $17.6 \mathrm{a}$ & $18.5 \mathrm{a}$ & $24.5 \mathrm{~b}$ & $14.8 \mathrm{a}$ & $23.9 \mathrm{~b}$ & $22.3 \mathrm{~b}$ \\
\hline $\mathrm{N}-\mathrm{NO}_{3}\left(\mu \mathrm{g} \mathrm{g}^{-1}\right)$ & $16.3 \mathrm{ab}$ & $18.3 \mathrm{~b}$ & $12.3 \mathrm{a}$ & $11.9 \mathrm{a}$ & $22.3 \mathrm{~b}$ & $13.1 \mathrm{a}$ \\
\hline $\mathrm{N}-\mathrm{NH}_{4}\left(\mu \mathrm{g} \mathrm{g}^{-1}\right)$ & $7.7 \mathrm{a}$ & $8.1 \mathrm{a}$ & $7.6 \mathrm{a}$ & $8.9 \mathrm{a}$ & $8.4 \mathrm{a}$ & $6.3 \mathrm{a}$ \\
\hline Proteases $\left(\mu \mathrm{g}\right.$ tiroxine $\left.\mathrm{g}^{-1}\right)$ & $99.0 \mathrm{a}$ & $117.2 \mathrm{a}$ & $102.2 \mathrm{a}$ & $128.0 \mathrm{~b}$ & $92.2^{\circ}$ & $98.2 \mathrm{ab}$ \\
\hline Deaminases $\left(\mu \mathrm{g} \mathrm{N} \mathrm{g}^{-1}\right)$ & $14.7 \mathrm{a}$ & $12.8 \mathrm{a}$ & $14.8 \mathrm{a}$ & $15.6 \mathrm{a}$ & 15.6 a & $10.9 \mathrm{a}$ \\
\hline
\end{tabular}

$\mathrm{S}=$ sandy soil; $\mathrm{SCL}=$ sandy-clay-loam soil; $\mathrm{SL}=$ sandy-loam soil.

Standard deviation $<10 \%$. Within each comparison, rows means followed by the same letters are not significantly different by the F-test in the analysis of variance $(\mathrm{p}<0.05) ;(\mathrm{n}=9)$.

tent was also greater in the lots planted with legumes but, in this case, only those containing M. ciliaris presented a significantly higher content than the control. The greater $\mathrm{N}_{-} \mathrm{NH}_{3}$ content could be due to rhizobium activity which is normally in symbiosis with this vegetable species. The $\mathrm{N}^{-\mathrm{NH}_{4}}$ content was more or less equal in all three experimental situations. In the lots containing legumes microbial activity, responsible for the mineralization of organic $\mathrm{N}$, was slightly inhibited. In fact, the PMN values were lower as compared to the control. This could be attributed to a greater quantity of $\mathrm{N}^{-\mathrm{NH}_{3}}$ coming from the fixing of atmospheric $\mathrm{N}$ by the rhizobia. Finally, the different vegetation cover did not seem to have influenced enzymatic activity. Considerable differences were found in the biological parameters of the different soils. Soils SCL and SL had a more intense microbiological activity expressed by the higher values of SIR and PMN. Nonetheless, the enzymatic activity was either comparable in the three soils (deaminases) or higher in soil S as compared to soils SCL and SL (proteases). Positive correlations were found between the SIR and TOC $\left(\mathrm{R}^{2}=0.75\right)$, TEC $\left(\mathrm{R}^{2}\right.$ $=0.82)$, total $\mathrm{N}\left(\mathrm{R}^{2}=0.97\right)$ and PMN $\left(\mathrm{R}^{2}=0.99\right)$. These correlations indicate, on the one hand, that the microbial population was more active in the soils containing the necessary nutrients for its growth (in particular $\mathrm{N}$ which often constitutes a limiting factor) and, on the other, that the activity of the ammonifying and nitrifying bacteria proceeded at the same rate as the total microbial activity.

\section{Molecular analyses}

In July 2004 and July 2006 different bacteria groups, the $\alpha$-proteobacteria, $\beta$-proteobacteria, nitrogen-fixing bacteria and ammonia oxidisers,

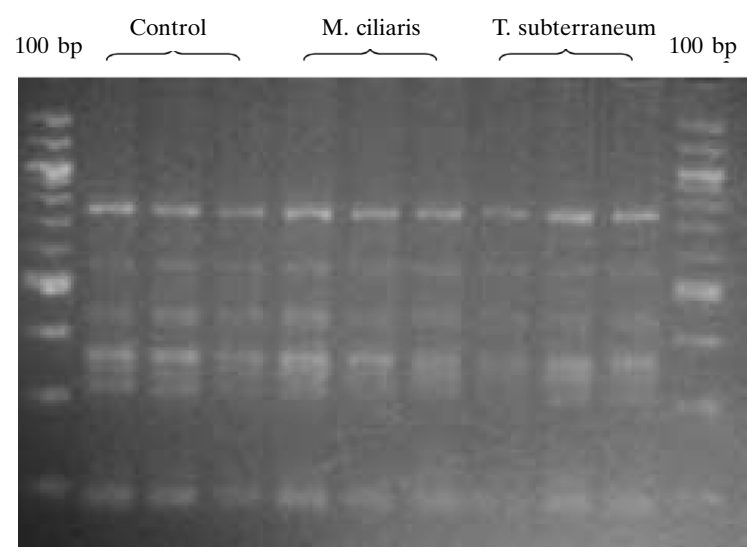

Figure 1. ARDRA electrophoretic profiles of 16S rDNA of $\alpha$-proteobcteria. Soils sampled on July 2004.

were isolated from soil samples of citrus plants and analysed using molecular techniques. Figure 1 shows the electrophoretic profiles of the $\alpha$-proteobacteria obtained using the ARDRA technique. No significant differences were found in the samples, the restriction enzyme Taq I generated an electrophoretic pattern of 7 bands of equal intensity, in which the fragments obtained are spread between about 750 and 180 bp. These results were confirmed by DGGE analyses (Fig. 2a). The same results were also obtained for the samples taken in July 2006, where the DGGE analysis produced electrophoretic patterns which were identical both in terms of number and band intensity (Fig. 2b). The $\beta$-proteobacteria and the nitrogen-fixing bacteria, and the ammonia oxidisers also produced similar results (data not shown). No significant differences were seen in the electrophoretic ARDRA and DGGE patterns in the various tests: the gels showed an equal 


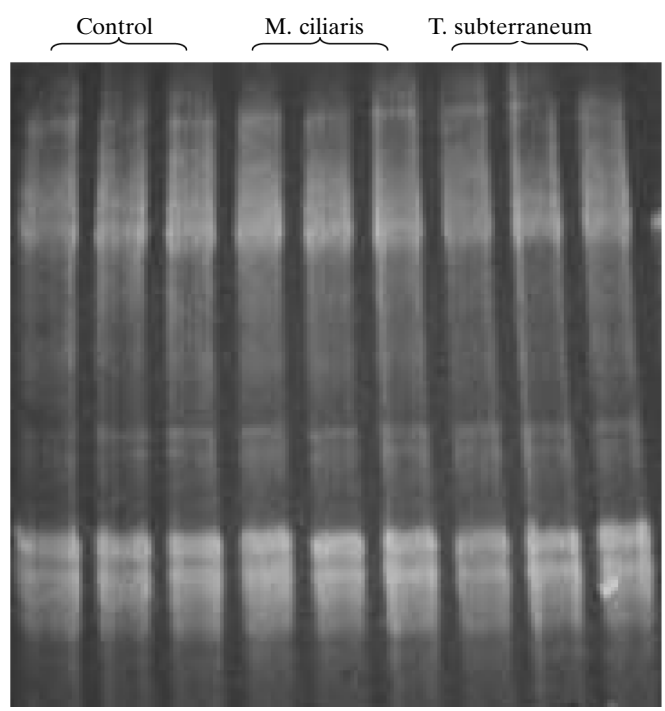

(a)

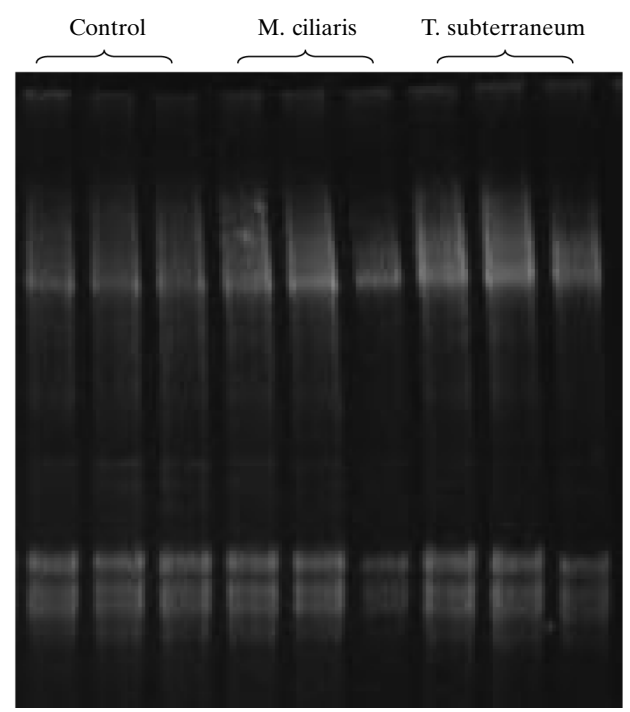

(b)

Figure 2. DGGE banding pattern of $16 \mathrm{~S}$ rDNA of $\alpha$-proteobacteria. Soils sampled on July 2004 (a) and July 2006 (b).

number of bands of equal intensities confirming that the samples were very similar. This result was obtained with the samples collected both in July 2004 and July 2006. Only the results relating to the sandy-loam soil (SL) are reported because those relating to the sandy soil (S) and the sandy-clay-loam soil (SCL) revealed a similar trend. Our results agree with that of Peixoto et al. (2006) who determined the effects of conventional tillage and no-tillage in crop systems with and without cover crops on bacterial structure. They reported differ- ences in response to cultivation, tillage and depth, but not due to cover cropping.

\section{Conclusion}

The research made it possible to highlight that legume crops produce an increase in microbial activity (SIR) and $\mathrm{N}-\mathrm{NH}_{3}$ content in the soil while they inhibit the activity of micro-organisms involved in the mineralization of organic $\mathrm{N}$. This last fact would seem to be correlated to the increase in $\mathrm{N}-\mathrm{NH}_{3}$ as a consequence of the fixing of atmospheric $\mathrm{N}$ by the symbiotic rhizobia. In the long term, the presence of legumes leads to an increase in TOC, TEC and total N. The increase in these parameters also occurs in areas producing spontaneous ground cover, even if to a lesser degree. This indicates that the use of cover crops brings about an improvement in soil fertility.

\section{Acknowledgements}

We wish to thank the financial support of the Italian Minister for Agricultural, Food and Forestry Policies, Project: "Innovazione per il raggiungimento della qualità globale in agrumicoltura" (AGRUQUAL).

\section{References}

Dinnes D.L., Karle D.L., Jaynes D.B., Kaspar T.C., Hatfield J.L., Colvin T.S., Cambardella C.A. 2002. Nitrogen management strategies to reduce nitrate leaching in tile-drained Midwestern soils. Agron. J., 94:153171.

Logsdon S.D., Kaspar T.C., Meek D.W., Prueger J.H. 2002. Nitrate leaching as influenced by cover crops in large soil monoliths. Agron. J., 94:807-814.

Sainju U.M., Singh B.P. 1997. Winter cover crops for sustainable agricultural systems. Influence on soil properties, water quality and crop yelds. Hort. Science, 32:21-28.

Campiglia E. 1999. Colture di copertura utilizzate in agroecosistemi mediterranei. Nota I: modificazioni dell'ambiente colturale. Riv. Agron., 33:90-103.

Benedetti A., Canali S., Alianiello F. 1998. La fertilizzazione organica dei suoli. I fertilizzanti organici. Edizioni L'Informatore Agrario, Bologna 1: 3-11.

Intrigliolo F., Stagno F. 2001. La fertilizzazione organica in agrumicoltura. Riv. Frutt., 63 - N. 11.

Nannipieri P., Dumontet S., Gianfreda L. 2005. Il suolo come sistema biologico. In: Sequi P. (ed.): Fondamenti di chimica del suolo, 148-174. Patron, Bologna, Italy. 
Muyzer G., Smalla K. 1998. Application of denaturing gradient gel electrophoresis (DGGE) and temperature gradient gel electrophoresis (TGGE) in microbial ecology. Mini review. Antonie van Leeuwenhoek, 73:127-141.

Caporali F., Campiglia E. 1993. Innovazioni nella ricerca di sistemi colturali a bassi input: l'impiego del trifoglio sotterraneo (Trifolium subterraneum L.) come "living mulch" e sovescio nella rotazione del frumento (Triticum estivum L.) - girasole (Helianthus annuus L.) Nota I Riv. Agron., 27:183-190.

Page A.L., Miller R.H., Keeney D.R. 1982. Methods of soil analysis, part 2. American Society of Agronomy Inc. Soil Science Society of America, Madison, Wisconsin, USA.

Anderson J.P.E., Domsch K.H. 1978. A physiological method for the quantitative measurement of microbiological biomass in soils. Soil Biol. Biochem., 10:215-221.

Drinkwater L.E., Cambardella C.A., Reeder J.D., Rice C.W. 1996. Potentially mineralizable nitrogen as an indicator of biologically active soil nitrogen. In: Doran J.W., Jones A.J. (eds.): Methods for Assessing Soil Quality, 217-229. SSSA Special Publication No. 49, Madison, Wisconsin, USA.

Keeney D.R., Nelson D.W. 1982. Nitrogen inorganic forms. In: Page A.L., Miller R.H., Keeney D.R. (eds.): Methods of soil analysis, part 2, 643-698. American Society of Agronomy Inc. Soil Science Society of America, Madison, Wisconsin, USA.

Kandeler E. 1993a. Bestimmung der Proteaseaktivität. In: Schinner F., Öhlinger R., Kandeler E., Margesin R. (eds.): Bodenbiologische Arbeitsmethoden, 180183. Springer-Verlag, Berlin, 2. Auflage.

Kandeler E. 1993b. Bestimmung der Arginin-Desaminierung. In: Schinner F., Öhlinger R., Kandeler E., Margesin R. (eds.): Bodenbiologische Arbeitsmethoden, 183-186. Springer-Verlag, Berlin, 2. Auflage.

Peoples M.B., Gault R.R., Lean B., Sykes J.D., Brockwell J. 1995. Nitrogen fixation by soybean in commercial, irrigated crops of central and southern New South Wales. Soil Biol. Biochem., 27:553-561.

Rochester I.J., Peoples M.B., Constable G.A., Gault R.R. 1998. Faba bean and other legumes add nitrogen to irrigated cotton cropping systems. Aust. J. Exp. Agric., 38:253-260.

Schwenke G.D., Peoples M.B., Turner G.L., Herridge D.F. 1998. Does nitrogen fixation of commercial dryland chickpea and faba crops in noth-west New South Wales maintain or enhance soil nitrogen? Aust. J. Exp. Agric., 38:61-70.
Spehn E.M., Scherer-Lorenzen M., Schmid B., Hector A., Caldeira M.C., Dimitrakopulos P.G., Finn J.A., Jumpponen A., O’Donnovan G., Pereira J.S., Schulze E.D., Troumbis A.Y., Körner C. 2002. The role of legumes as a component of biodiversity in a crossEuropean study of grassland biomass nitrogen. OIKOS, 98:205-218.

Peoples M.B., Crashwell E.T. 1992. Biological nitrogen fixation: investments, expectations and actual contribution to agriculture. Plant Soil, 49:13-39.

Gomes N.C.M., Heuer H., Schönfeld J., Costa R., Mendoça-Hagler L., Smalla K. 2001. Bacterial diversity of the rhizosphere of maize (Zea mays) grown in tropical soil studied by temperature gradient gel electrophoresis. Plant Soil, 232:167-180.

Weisburg W.G., Barns S.M., Pelletier D.A., Lane D.J. 1991. 16S ribosomal DNA amplification for phylogenetic study. J. Bacteriol., 173:697-703.

Heuer H., Smalla K. 1997. Application of denaturing gradient gel electrophoresis and temperature gradient gel electrophoresis for studying soil microbial communities. In: van Elsas J.D., Wellington E.M.H., Trevors J.T. (eds.): Modern Soil Microbiology, 353373. Marcel Dekker, Inc., New York.

Brosius J., Dull T.J., Sleeter D.D., Noller H.F. 1981. Gene organization and primary structure of a ribosomal RNA operon from Escherichia coli. J. Mol. Biol., 148:107-127.

Nübel U., Engelen B., Felske A., Snaidr J., Weisenhuber A., Amann R.I., Ludwig W., Backhaus H. 1996. Sequence heterogeneities of genes encoding 16S rRNAs in Paenibacillus polymyxa detected by temperature gradient gel electrophoresis. J. Bacteriol., 178:56365643.

Smit E., Leeflang P., Wernars K. 1997. Detection of shifts in microbial community structure and diversity in soil caused by copper contamination using amplified ribosomal DNA restriction analysis. FEMS Microbiol. Ecol., 23:249-261.

Kowalchuk G.A., Stephen J.R., De Boer W., Prosse J.I., Embley T.M., Woldendorp J.W. 1997. Analysis of ammonia-oxidizing bacteria of the $\beta$ subdivision of the class Proteobacteria in coastal sand dunes by denaturing gradient gel electrophoresis and sequencing of PCR-amplified 16S ribosomal DNA fragments. Appl. Environ. Microbiol. 63:1489-1497.

Peixoto R.S., Coutinho H.L.C., Madari B., Machado P.L.O.A., Rumjanek N.G., Van Elsas J.D., Seldin L., Rosado A.S. 2006. Soil aggregation and bacterial community structure as affected by tillage and cover cropping in the Brazilian Cerrados. Soil Tillage Res., 90:16-28. 